\title{
Fracas over \$5 million Gulf syndrome grant
}

Meredith Wadman

The battle over Gulf War syndrome has broken out again — this time over a US\$5 million grant. The funding has been granted, without peer review, to the laboratory of clinician Robert Haley, whose research on veterans is controversial.

Haley's work suggests that wartime chemical exposure caused brain damage in veterans. US Senator Kay Bailey Hutchison (Republican, Texas) has earmarked \$5 million from the 2001 spending law for the Department of Defense (DoD) specifically for GulfWar illness research at the University of Texas Southwestern Medical Center in Dallas, where Haley works.

"The senator felt Haley was producing some breakthrough research," says a spokeswoman for Hutchison.

But Bernard Rostker, the DoD's special assistant for Gulf War illnesses, disagrees with the decision. "If Senator Hutchison wants special treatment and is willing to explicitly authorize it through legislation, more power to her," Rostker told Nature. "But it was not something we [at the DoD] were going to do again after being disappointed the first time."

The $\$ 17$ million spent annually by the defence department on Gulf War research is allocated by soliciting proposals on specific

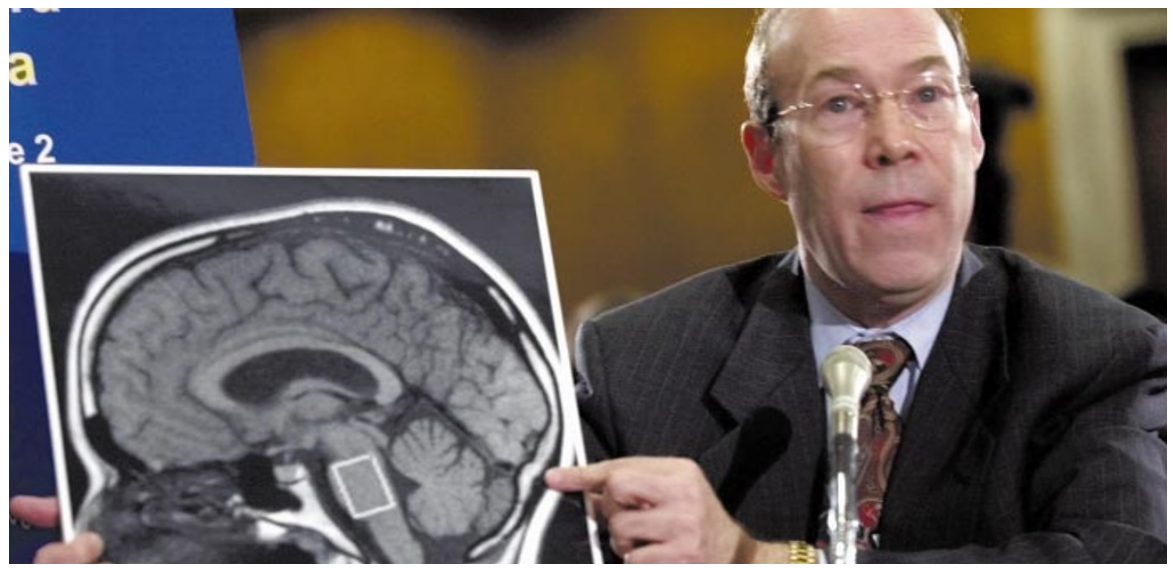

Brain storm: Robert Haley convinced senators to fund him, but some researchers dispute his work.

themes. These are peer-reviewed by panels of independent, non-government scientists. Haley twice failed to win funding in this way. But in 1997, under political pressure to be seen to be taking possible chemical causes of veterans' maladies seriously, the DoD bypassed the process and granted Haley $\$ 3$ million. The grant expired last autumn.

Rostker, who supported Haley's original grant, argues that Haley should not "be given special treatment" a second time. He says Haley failed to repeat his original work in a fresh group of veterans who served in the

\section{Jury to rule on 'defamatory' paper}

\section{Rex Dalton, San Diego}

A jury in Arizona is to decide whether the authors of a peer-reviewed paper challenging another scientist's results are guilty of defamation.

The decision to set up a jury trial, made by the state court late last month, is the latest twist in a long-running legal battle involving Ronald Dorn, a geography professor at Arizona State University. Dorn is suing the authors of an article published in Science $(280,2132-2139 ; 1998)$ in which they questioned his rock-dating methods.

He has settled out of court with one of the paper's co-authors, Wallace Broecker, a prominent Earth scientist at Columbia University, and has opted not to pursue his claims against two in Switzerland.

The remaining co-authors are Warren Beck, Douglas Donahue, Tim Jull and George Burr at the University of Arizona in Tucson, and archaeologist Ekkehart Malotki of Northern Arizona University in Flagstaff.

Dorn's method involves scraping varnish off a rock surface, treating it, and then dating it using radiocarbon analysis. In the Science article, the defendants claimed to have found traces of coal and charcoal in Dorn's samples, which they said could distort the dating results.

At a state court hearing in Phoenix last month, Dorn's attorney argued that the authors of the Science paper were involved in "manipulation of the data to make it appear [Dorn] intentionally salted" his samples, which was scientific misconduct.

Paul Carter, the Arizona assistant attorney-general defending the authors, denied the allegations. He noted that some senior science administrators at the University of Arizona judged the article to be within the scope of the researchers' employment. These administrators argued that the manuscript had received extraordinary legal and scientific review before being submitted to Science.

Carter sought dismissal of the case on the grounds that the article was a product of research work. But court judge Edward Burke said the dispute over whether the authors "exceeded all of the bounds of acceptable research and commentary" raises a question of fact that can only be decided by a jury. The trial will start in October.
Gulf and another that did not, as he had agreed to do. Haley disputes this, saying he agreed only to study a new group of Gulf veterans. (He spent $\$ 2.3$ million of the grant doing new studies, mainly on his original sample population.)

"We have published the overwhelming majority of the positive literature that has led to information on what's wrong with these [veterans]," says Haley, "and yet we are unable to get funding. You've got politics paralysing the research process."

Some scientists disagree with this, however. "Dr Haley has basically bypassed the peer-review mechanism," says Philip Landrigan, an epidemiologist at the Mount Sinai School of Medicine in New York, who has written that Haley's studies are methodologically flawed. "That's worrisome. Peer review is a bedrock principle."

Haley published three articles in the Journal of the American Medical Association in 1997 (see Nature 385, 187; 1997 and 407, $819 ; 2000)$. The studies, on 249 members of a Naval Reserve construction battalion that served in the Gulf, identified three neurological "syndromes" and linked them to different self-reported chemical exposures. The most interesting results derived from intensive research on 30 of the veterans.

Critics, including the Institute of Medicine (see Nature 407, 121; 2000), have cited the small sample sizes and possible selection bias as flaws in the work. Haley has continued to publish new results using the same smaller group in peer-reviewed journals such as Archives of Neurology and Toxicology and Applied Pharmacology.

Ross Perot, the Texas billionaire and former presidential candidate, defends Hutchison's actions. "These goofballs in the Pentagon are trying to just sell stress [as the cause of Gulf War illnesses] and not do anything for the men," he says. Perot's private foundation has given Haley \$2.6 million in donations over seven years. 